\title{
Revisiting Substrate Specificity Concept in Microbial Screening Methodologies for Fish Waste Management
}

\author{
Amala Panaparambil Vakkachan ${ }^{1}$, Sumithra Thangalazhy Gopakumar ${ }^{1, *} \mathbb{B}$, Reshma \\ Kalarical Janardhanan ${ }^{1}$, Anusree Velappan Nair ${ }^{1}$, Sayooj P. ${ }^{1}$, Vijayagopal P. ${ }^{1}$
}

\begin{abstract}
${ }^{1}$ Marine Biotechnology Division; ICAR-Central Marine Fisheries Research Institute (ICAR-CMFRI), Post Box No. 1603, Kochi-682 018, India.
\end{abstract}

\section{How to cite}

Amala, P. V., Sumithra, T. G., Reshma, K. J., Anusree, V. N., Sayooj, P., Vijayagopal, P. (2021). Revisiting Substrate Specificity Concept in Microbial Screening Methodologies for Fish Waste Management. Turkish Journal of Fisheries and Aquatic Sciences, 21, 323-332. http://doi.org/10.4194/13032712-v21_7_02

\section{Article History}

Received 09 December 2020

Accepted 31 March 2021

First Online 07 April 2021

\section{Corresponding Author}

Tel.: +09495466030

E-mail: sumithravet@gmail.com

\section{Keywords}

Functional screening

Fish protein

Fish oil

Hydrolytic microbes

\begin{abstract}
Microbial and enzymatic processing is an attractive area for production of valuable byproducts from fish waste. Functional screening methodologies for the purpose are still based on activities in non-specific substrates, and concept of substrate specificity is not yet validated. Therefore, reliability of using non-specific substrate for the purpose was checked. Results revealed the existence of a limited number of mutually inclusive positive isolates in non-specific and specific substrate based assays ( $13 \%$ for fish proteolysis and $22 \%$ for fish lipolysis), with no significant positive correlations $(P>0.05)$. Further, using non-specific substrates in screening assays missed $57.1 \%$ and $53.33 \%$ of fish proteolytic and fish lipolytic microbes respectively, signifying the use of same substrates. Beyond methodological perspectives, the paper forms the first report on fish proteolytic activity of Bacillus tropicus, Bacillus vallismortis, Paenibacillus alvei, Staphylococcus epidermidis and Staphylococcus hominis. Similarly, fish oil hydrolyzing capacities of B. tropicus, Cronobacter sakazakii, P. alvei, Paenibacillus pinisoli, Pantoea stewartii, S. hominis and Staphylococcus caprae are recorded for the first time. Further, the paper points out 6 and 3 potential microbial species producing $>1$ protease units $/ \mathrm{ml}$ and $>1$ enzymatic index for fish proteolytic and lipolytic activities, without any optimization, warranting future use in fish waste management.
\end{abstract}

\section{Introduction}

Effective management and disposal of fish waste is a well-recognized stinging issue worldwide in both urban and rural areas, having serious impacts on environment (Dauda et al., 2019). Management of fish waste is identified upon two major strategies; the first one being the recovery of marketable by-products from fish wastes and, the other one is reducing deleterious effects of fish wastes before being discharged to the environment (Dauda et al., 2019). Numerous investigations have been carried out worldwide, for exploring environment friendly, efficient and cost effective techniques for addressing these strategies.
Among these, enzymatic processing and microbial fermentation methods are widely targeted tools providing ideal opportunities for production of valuable byproducts from fish and seafood waste (Fernandes, 2016). Amid the varied sources of enzymes viz., animals, plants and microbes, microbial sources are preferred, due to the ease in cultivation and manipulation techniques (Singh et al., 2016). Proteases and lipases are the two categories of enzymes that are actively sought in the enzymatic processing and microbial management of fish waste, as the major composition of fish waste include protein (58\%) and fat (19\%) (Ramakrishnan et al., 2013; Siddik et al., 2021). Apart from acting as an enzymatic source, microbes capable of hydrolyzing fish 
protein/lipids have direct applications in composting fish waste as they can accelerate the process, resulting in efficient and valuable organic fertilizer.

Conventional approach for screening protein and lipid hydrolytic microbes is through cultivation in general substrate embedded media (Gopinath et al., 2005; de Oliveira et al., 2016). Hydrolysis of organic substrates by different bacteria is an extremely complex phenomenon controlled by various mechanisms, including substrate induction, nutritional stresses, and catabolite repression (Daroit et al., 2014), suggesting the probability for substrate specificity of microbial hydrolytic activities (Motyan et al., 2013). On contrast, selection of microbes for many downstream applications in fish waste management are still based on activities in conventional substrate embedded media viz., nutrient agar embedded with $1 \%$ skim milk protein (SMP) and 1\% tween 80 (T80) for fish proteolytic microbes and fish lipolytic microbes respectively (Rebeca et al., 1991; Gopinath et al., 2005). Neither studies have been conducted nor have scientific evidences been gathered on the reliability of using routine media for screening of enzymes/ hydrolytic microbes for fish waste management /processing. The concern was further reinforced by the observations of De Oliveira et al. (2016) on substrate specificity of one Bacillus sp. on feathers over cheese-whey powder and human hair. At the same time, wide scale screening through the most suitable methodologies forms the critical decisive step in any industrial processes/ field applications involving microorganisms (Haki \& Rakshit, 2003). In this scenario, the study was primarily aimed to check the reliability of using general substrates for the functional screening of microbes/microbial enzymes that can hydrolyze fish protein/ fish oils. In line to these, the study pointed out and identified the potential isolates that can have final applications for degrading fish proteins and fish oils.

\section{Materials and Methods}

\section{Bacterial Strains}

A total of 59 bacterial strains isolated from various sources (Table 1 ) were used in the study.

\section{Proteolytic Activity in Routine Screening Media}

Bacterial strains were initially screened for extracellular protease production in the routine screening media (nutrient agar embedded with $1 \%$ skim milk protein, SMP) (de Oliveira et al., 2016). The plates were incubated for 7 days at $30^{\circ} \mathrm{C}$ and observed for clear zone formation.

\section{Proteolytic Activity in Fish Protein Based Media}

Bacterial isolates were spotted onto specific substrate embedded agar plates namely M9 minimal media with $20 \%$ crude fish protein hydolysate, CFPH (Belchior \& Vacca, 2006). CFPH was prepared by following the protocol of Wisuthiphaet et al. (2016) and stored at $4^{\circ} \mathrm{C}$ till use. Proximate analysis (on dry matter basis) by the methods of AOAC (2003) showed that the used CFPH consisted of crude fibre $(0.6 \%)$, crude protein (62\%), crude ash (9.68\%), crude fat $(5.7 \%)$, nitrogen free extract (22\%) and acid insoluble ash (0.02\%). Isoelectric point ( $\mathrm{pl}$ ) value of the used CFPH was calculated as 4.22. The plates were then incubated for 7 days at $30^{\circ} \mathrm{C}$ and observed for clear zone formation (Fungaro \& Maccheroni, 2002).

\section{Lipolytic Activity in Routine Screening Media}

Bacterial isolates were analyzed in routine lipase screening media (phenol red nutrient agar plates containing $1 \%$ Tween 80, T80). The plates were incubated for 7 days at $30^{\circ} \mathrm{C}$ and observed for color change. A color change from red to yellow was recorded as positive, while no color change was inferred as negative (Singh et al., 2006).

\section{Lipolytic Activity in Fish Oil Based Media}

The isolates were spotted onto specific substrate embedded phenol red agar plates (M9 minimal media containing $1 \%$ crude fish oil) (Belchior \& Vacca, 2006). The oil was extracted from minced fish flesh by following the protocol of Bandarra et al. (2001). Fatty acid composition of extracted oil (Bligh and Dyer 1959) indicated that it contained $47.9 \%$ total polyunsaturated

Table 1. Bacterial strains used in the study

\begin{tabular}{|c|c|}
\hline Isolate ID & Isolation source \\
\hline $\begin{array}{l}\text { CMFRI/BTr-01; CMFRI/55b; CMFRI/StE-06; CMFRI/SHo-02; CMFRI/142b; CMFRI/162b; CMFRI/169b; } \\
\text { CMFRI/226b; CMFRI/StE-05; CMFRI/209b; CMFRI/218b; CMFRI/6b; CMFRI/119b; CMFRI/StCa-01; } \\
\text { CMFRI/120b; CMFRI/BS-25; CMFRI/BA-16; CMFRI/33b }\end{array}$ & Marine mussels \\
\hline CMFRI/Mrs2; CMFRI/B2; CMFRI/Na1 & $\begin{array}{l}\text { Fish pond } \\
\text { sediment }\end{array}$ \\
\hline $\begin{array}{l}\text { CMFR1/PaP-01; CMFRI/BA-17; CMFRI/Sa22; CMFRI/Sa21; CMFRI/A1; CMFRI/A3; CMFRI/BS-29; CMFRI/A6; } \\
\text { CMFRI/A9; CMFRI/A10; CMFRI/A12; CMFRI/A15; CMFRI/PaA-01; CMFRI/BS-30; CMFRI/A22; CMFRI/A23; } \\
\text { CMFRI/BF-02; CMFRI/A26; CMFR1/PSt-01; CMFRI/A28; CMFRI/BS-26; CMFRI/A34; CMFRI/A45; CMFRI/A46; } \\
\text { CMFRI/A47; CMFRI/A48; CMFRI/A49; CMFR1/Csa-01; CMFRI/A52; CMFRI/BS-28; CMFRI/A54; CMFRI/A55; } \\
\text { CMFRI/BS-27; CMFRI/A57; CMFRI/A58; CMFR1/Bva-01;CMFRI/A62;CMFRI/A63 }\end{array}$ & $\begin{array}{c}\text { Marine fish } \\
\text { waste }\end{array}$ \\
\hline
\end{tabular}


fatty acids (PUFA), 23.1\% total monounsaturated fatty acids and $28.4 \%$ total saturated fatty acids. Of the total PUFAs, $\omega 3$ and $\omega 6$ constituted $39.4 \%$ and $2.5 \%$ respectively. Eicosapentaenoic acid (EPA) and docosahexaenoic acid (DHA) formed $18.4 \%$ and $12.5 \%$ of total $\omega 3$ fatty acids. After spotting with different bacterial isolates, the plates were incubated for 7 days at $30^{\circ} \mathrm{C}$. At the end of incubation, the plates were observed for color change and results were noted as positive and negative as similar to routine screening media (Singh et al., 2006).

\section{Validation of Fish Protein Degrading Activity}

Validations of fish protein degrading activities were performed for the selected bacterial isolates in specific substrate embedded media i.e. M9 minimal broth containing CFPH $(10 \mathrm{~g} / \mathrm{L})$ as the sole source of carbon, nitrogen, and energy was used as the media. After inoculation with the selected isolates, each tube was incubated at $30^{\circ} \mathrm{C}$ for 7 days. At the end of incubation, culture supernatants were utilized for determination of proteolytic activity using either casein or CFPH as substrate (Anson, 1938). One unit of enzyme activity was defined as the amount of enzyme required to liberate $1 \mu \mathrm{mol}$ of tyrosine per min under defined assay conditions (George-Okafor \& Mike-Anosike, 2012).

\section{Validation of Fish Oil Degrading Activity}

Positive fish oil (FO) degrading bacterial isolates were spotted onto specific substrate embedded agar plates namely M9 minimal media with $1 \%$ crude FO. The plates were incubated for 7 days at $30^{\circ} \mathrm{C}$ and observed for clear zone formation. In case of positive isolates forming clear zone, zone diameter was measured (difference between total zone diameter and bacterial colony diameter). The assay was replicated to confirm the activity and mean zone diameter was taken for analysis. Enzymatic index (EI) of the positive isolates was calculated by dividing the average zone diameter with average colony diameter (Fungaro \& Maccheroni, 2002).

\section{Identification of Fish Protein/Oil Hydrolytic Microbes}

Identification of FP and FO hydrolyzing isolates were carried out through polyphasic taxonomic approach. For that, 16SrRNA gene was amplified from each purified culture using universal primers (Weisburg et al., 1991) and was sequenced at Agrigenome, India. The sequences were compared with those in GenBank database, National Center for Biotechnology Information (NCBI) using nucleotide BLAST with default parameters. Sequence identities of $97 \%$ and $99 \%$ were taken as the benchmarks for genus and species assignments, respectively (Janda \& Abbott, 2007). The results of $16 S r R N A$ gene characterization were compared with that of conventional microbiological tests (Bergey et al., 2012) for final identification of bacteria. Subsequently, the 16SrRNA gene sequences were deposited in GenBank, NCBI.

\section{Phylogenetic Analysis}

Overlapping 945 bp size segment of 16SrRNA gene from positive isolates was used for phylogenetic analysis using MEGA version 10 (Kumar et al., 2018). The sequences were aligned using ClustalW and neighborjoining (NJ) tree was constructed using Kimura 2parameter model. The confidence in the $\mathrm{NJ}$ tree was estimated by 1000 bootstrap replicates.

\section{Statistical Analysis}

After checking the normality of the data using Kolmogorov-Smirnov test (SPSS ver. 16), influence of substrate on protease and lipase activity was tested by the comparison between zone diameters in SMP and CFPH embedded media, and between T8O and FO embedded media using, Mann-Whitney $U$ test. Then, Kendall's Tau correlation plot representing correlation between zone diameters in all 4 different media (CFPH, SMP, FO and T80) and matrix plot representing the presence/ absence of activities in all 4 different media were designed using PAST3.26 software (Hammer et al., 2001). In the similar manner, Kendall's Tau correlation between quantitative profiles of fish proteolytic isolates in assays using either SMP or CFPH as substrates, as well as between zone diameters and quantitative profiles of fish proteolytic bacteria were also found out. Further, associations between results of T80 and FO embedded agar plates was found out using Chi-Square test via SPSS version 16. Inter-assay associations between quantitative and qualitative methods employed for fish lipolytic and proteolytic bacteria was calculated using Chi-Square test via SPSS version 16 . In all tests, levels of significance were checked at $\mathrm{P}<0.05$.

\section{Results and Discussion}

There are three main ways to retrieve bioactive materials/products from fish waste viz., physicochemical methods, enzymatic methods (using commercial proteases and lipases) and microbial fermentation methods. Among these three methods, the latter two are considered as superior (Villamil et al., 2017; Araujo et al., 2020). As fish waste hydrolyzing microorganisms are the most important resources for both of these methods, selection of the appropriate microbes through proper functional screening methodologies plays a critical role in success of fish waste management (Rudolf et al., 2014). Keeping view on these facts, the present investigation was targeted to generate basic insights on screening media and assay selection, in a different dimension, which fetches applications during functional screening of 
microbes/enzymes for the production of valuable byproducts from fish waste.

Screening of microbes/enzymes for many downstream applications including fish waste management is still based on activities in general substrate embedded media, irrespective of their final intended use (Sumathi et al., 2012; Rai et al., 2014). Importance of determining substrate specificity of microbial lipolytic enzymes for application in pulping industry was highlighted by Ramnath et al. (2017). While, least attention has been devoted to the concept of substrate specificity in fish waste management and, conventional screening substrates for bacterial proteases and lipases viz., skim milk protein (SMP) and tween 80 (T80) respectively, was blindly used by different researchers for screening of fish proteolytic/ fish lipolytic microbes. Reliability of these conventional substrates for screening fish protein/ fish oil degrading microbes was checked through the present study. For this, 59 unique isolates from varied sources were screened for their protease and lipase activities on both routine screening media and fish substrate based media. In SMP embedded media for screening proteolytic microbes, 38 (64.41\%) bacterial isolates were found to be positive, producing a clear zone around the spot of inoculation. In the routine screening media for lipolytic microbes (T80 agar), 24 isolates (40.68\%) were found to be positive, giving a color change of the media from pink to yellow. Our observation on higher proportion of proteolytic microbes than lipolytic microbes was parallel to the earlier reports that proteases are the most ubiquitous enzymes among microbes irrespective of the source (Sharma et al., 2017). Subsequently, all the isolates were screened by identical protocols, except for the substrates used in screening media. In other words, fish protein (FP) and fish oil (FO) were used instead of SMP and T80 in routine protocol. It was interesting to find that only 14 (23.72\%) and 15 (25.42\%) isolates were positive in FP and FO based media respectively. All these positive isolates in the preliminary screenings were subsequently validated for their activities in quantitative terms and then characterized up to species level based on polyphasic taxonomical approach, the results were detailed in the following sections. Another interesting observation during the preliminary screening methodologies was, many isolates having activity in FP/FO embedded media was not functional in SMP/T80 media and vice versa (Fig. 1). Out of total 46 proteolytic and 32 lipolytic isolates, only 6 (13\%) and 7 (21.88\%) were having activities in both proteolytic as well as in both lipolytic media respectively (Fig. 2). In order to clarify, whether these observations/ results were statistically significant or not, Mann-Whitney U test was conducted, which showed that substrate embedded in
Fig. 1a

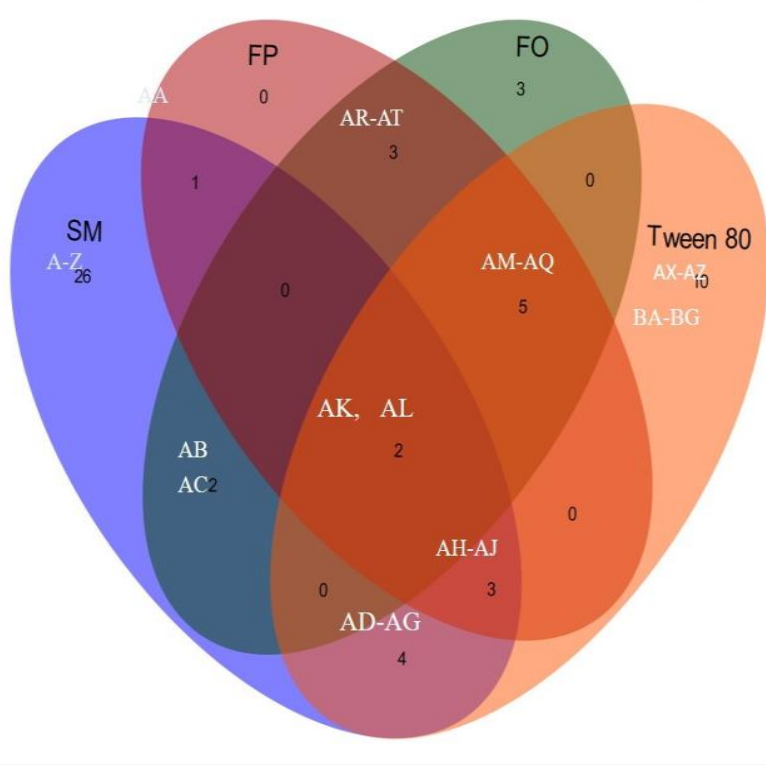

Fig. 1b

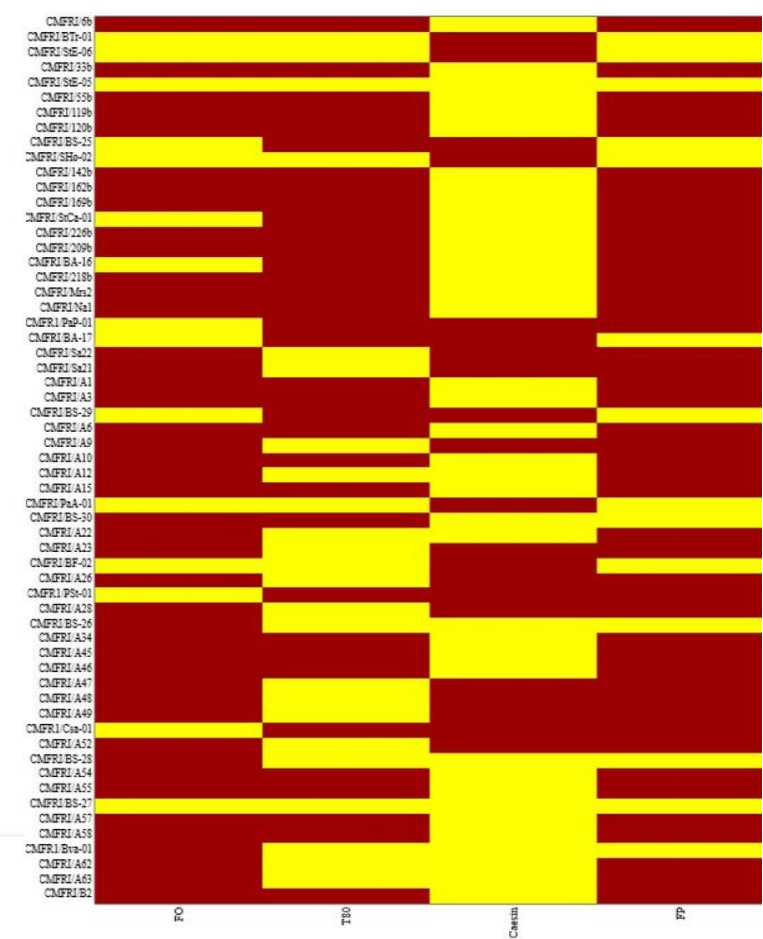

Figure 1. Shared bacterial isolates in each substrate based assays 1a: Classic Venn diagram representing shared bacterial isolates in each assays Abbreviations: A: CMFRI/226b*; B: CMFRI/A58; C: CMFRI/A57; D: CMFRI/A55; E: CMFRI/A54; F: CMFRI/A46; G: CMFRI/A45; H: CMFRI/A34; I: CMFRI/A15; J: CMFRI/A10; K: CMFRI/33B; L: CMFRI/Mrs2; M: CMFRI/A6; N: CMFRI/A3; O: CMFRI/A1; P: CMFRI/120b; Q: CMFRI/B2; R: CMFRI/209b; S: CMFRI/Na1; T: CMFRI/169b; U: CMFRI/6b; V: CMFRI/162b; W: CMFRI/218b; X: CMFRI/55b; Y: CMFRI/142b; Z: CMFRI/119b; AA:CMFRI/BS-30; AB: CMFRI/BA-16; AC:CMFRI/StCa-01; AD: CMFRI/A6; AE: CMFRI/A62; AF: CMFRI/A22; AG: CMFRI/A12; AH:CMFR1/Bva-01; Al: CMFRI/BS-28; AJ: CMFR1/BS-26; AK: CMFRI/BS-27; AL: CMFRI/StE-05; AM: CMFR1/BF-02; AN: CMFRI/PaA-01; AO: CMFRI/SHo-02; AP: CMFRI/BTr-01; AQ: CMFRI/StE-06; AR: CMFRI/BS-25; AS: CMFRI/BS-29; AT: CMFRI/BA-17; AU: CMFR1/Csa-01; AV: CMFR1/PSt01; AW: CMFR1/PaP-01; AX: CMFRI/A52; AY: CMFRI/A49; AZ: CMFRI/A48; BA: CMFRI/A47; BB: CMFRI/A28; BC: CMFRI/BS-26 ; BD: CMFRI/A23; BE: CMFRI/Sa22; BF: CMFRI/Sa21; BG: CMFRI/A9 * Culture ID for isolates

1b: Matrix plot representing the activity of each strain

Yellow color indicates positive reaction and maroon color indicates negative reaction. Culture ID is given on the Y axis. T80: Tween 80; FO: Fish oil; FP: Fish protein 
Fig. 2a

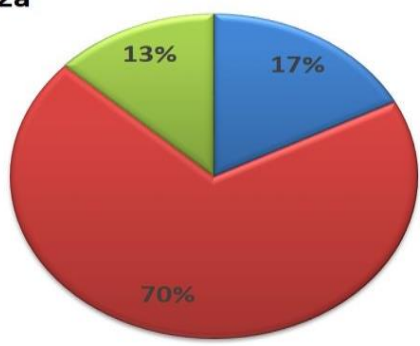

Fig. 2b

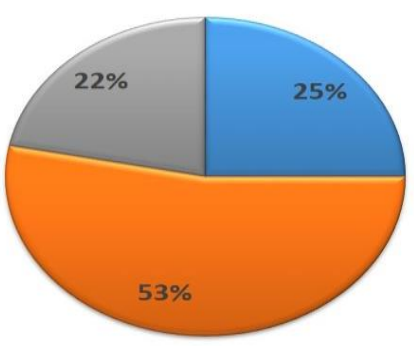

$\square$ FO

T80

Both

Figure 2. Results of primary screening for proteolytic and lipolytic bacterial isolates 2a: Primary screening for proteolytic isolates through two different substrate based assays Abbreviations: SMP: Skim Milk Protein; FP: Fish protein

2b: Primary screening for lipolytic isolates through two different substrate based assays Abbreviations: T80: Tween 80; FO: Fish oil

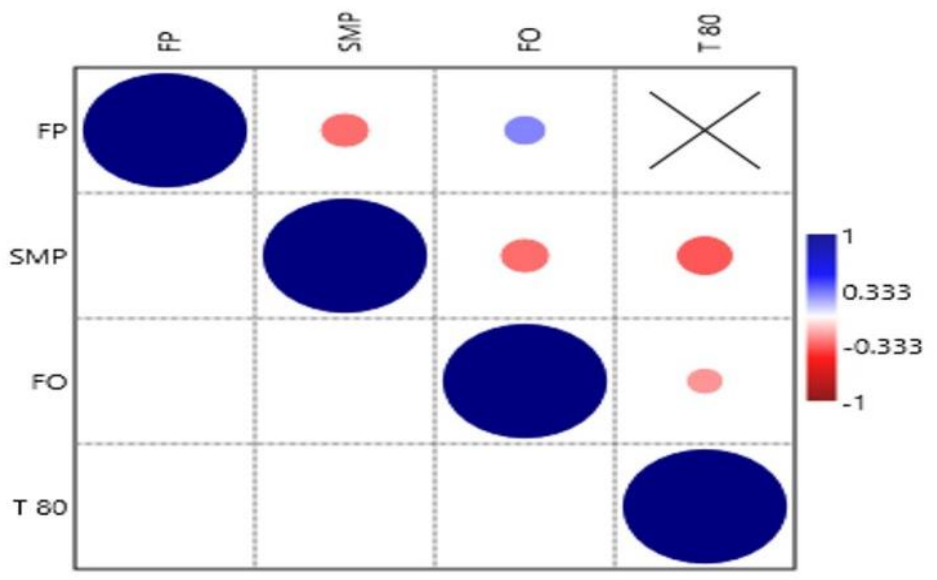

Figure 3. Kendall's $\tau$ correlations between proteolytic and lipolytic activities in specific and non-specific substrates Abbreviations: SMP: Skim Milk Protein; FP: Fish protein; T80: Tween 80; FO: Fish oil

the screening media had a significant influence $(P<0.05)$ on both proteolytic and lipolytic activity. More importantly, there was no significant positive correlations $(P>0.05)$ between the profiles in both proteolytic and lipolytic media (Fig. 3). Instead, a significant negative correlation $(\tau=0.28, p=0.001)$ was found to be existing between activity profiles in FP and SMP embedded media. Further, during validation of fish protein hydrolysis, there was no significant correlation $(\tau=0.27, p=0.12$ ) between the profiles in assays using either FP or SMP as substrate, again demonstrating the substrate specificity of fish protein lysing microbes. Similarly, there was no significant associations $(P>0.05)$ between phenol red assay results in T80 and FO embedded agar plates $(\chi(1)=0.299, p=.585)$ with Phi and Cramer's Value as 0.071. More interestingly, a significant negative correlation ( $\tau=0.202, p=0.02$ ) was found to be existing between the validation results for fish oil hydrolysis, emphasizing the substrate specificity of fish oil lysing microbes. Low selectivity of primary screening method is allowed for functional microbial screening in order to capture a wide variety of positive hits. Nevertheless, the present study observed that there was only a low percentage of mutually inclusive positive isolates in FP vs SMP as well as in FO vs T80 based assays. Further, there was no significant positive correlation between the profiles of these substrate based assays. The results also indicated that, using general substrate in the screening assays of fish waste management could miss wide range of positive hits. Thus, the sturdy recommends to use fish based substrates (FP/FO) in the primary assays of functional screening itself; whenever, the final aim is to find out microbes for fish waste management. Simultaneously, this will help in effectively managing time as well as cost during screening methodologies. The information can be very critical as proteases and lipases from microorganisms are the most extensively sought industrial enzymes for many formulations in fish waste management (Soleymani et al., 2017; Xiao et al., 2018; Siddik et al., 2021). In short, the action of FP and FO lysing microbes were found to be highly substrate specific, which might be attributed to the differences in the composition and structure of the protein or lipid in SMP/FP and FO/T80 (USDEC, 2005; Iko et al., 2015). In parallel to our observations, De Oliveira et al. (2016) had noted the substrate specificity of Bacillus sp. CL33A on feathers over cheese-whey powder and human hair. 
Further, substrate specificity of microbial lipases having applications in pulp and paper was demonstrated by Ramnath et al. (2017).

As many screening assays are available to investigate proteolytic and lipolytic activity of microbes, our next aim was to explore whether the used primary screening methodology for fish proteolytic and lipolytic activities were having significant relation with the corresponding validation method. Results showed that activities in initial screening and subsequent validation using FP as substrate had statistically significant strong, positive correlations $(\tau=0.712, p=0.001)$. This proved that results in FP based plate assay can be an approximate good indicator of fish protein degrading potential. For the initial screening for FO degrading microbes, FO embedded M9 minimal media agar plates having phenol red (PR) as indicator was used. The basic principle in PR based lipase assay is that, a slight drop in $\mathrm{pH}$ from 7.3 (end point of PR dye) to a more acidic $\mathrm{pH}$, due to the release of fatty acids following lipolysis, leads to a color change from red to orange/ yellow (Kumar et al., 2012; Rai et al., 2014). Similar to proteolytic assays, statistically significant strong positive association $(P<0.05)$ with $\mathrm{Phi}$ and Cramer's Value as 0.82 was observed between the results of initial screening and subsequent validation methods for fish lipolytic bacteria. Further, none of the negative isolates in the validation assay were negative in initial screening, proving the high sensitivity of PR test, a property essential in primary screening method in order to capture a wide variety of positive hits (Rastall, 2007). The significant strong positive association and high sensitivity suggested that PR assay in FO embedded media can be an approximate good indicator of FO degrading potential of microbes. Supporting our observation, high sensitive nature of $P R$ test for detecting lipase activity in olive oil and tributyrin had been reported (Lanka \& Latha, 2015). Based on their results Ramnath et al. (2017) has recommended phenol red agar plates for screening lipolytic activity of microbes, further supporting the results of the present study.

All fish proteolytic and fish lipolytic isolates were characterized up to species level based on polyphasic taxonomical approach comprising conventional microbiological tests and 16SrRNA gene sequencing (Bergey et al., 2015). 16SrRNA gene sequences of positive isolates were then submitted to GenBank (NCBI) and got assigned with accession numbers (Table 2). Altogether, there was 8 and 11 distinct fish proteolytic and lipolytic bacterial species respectively, from 3 and 5 different genera. Broadly, all fish proteolytc isolates belonged to Gram positive bacteria under the phylum Firmicutes. Among fish lipolytic isolates, majority of the isolates (86.67\%) were Gram positive under the phylum Firmicutes, while a minor portion belonged to gram negative under phylum Proteobacteria (13.33\%). In accordance with our results, gram positive bacteria, particularly Bacillus spp. were reported as the best producers of different extracellular commercial enzymes (Ruginescu et al., 2020), while there is a clear paucity of different waste degrading/ enzyme production potentials in Gram negative bacteria (de Lourdes et al., 2013). The identified bacterial species were classified in 5 different families (Fig. 4). There were 7 bacterial species having both FP and FO hydrolytic activity (Table 2). Even though fish protein degrading activity of different bacterial species had been recorded (Samad et al., 2017; Wang et al., 2019), fish proteolytic potential of Bacillus tropicus, Bacillus vallismortis, Paenibacillus alvei, Staphylococcus epidermidis and Staphylococcus hominis observed in the present study

Table 2. Identification of fish proteolytic and fish lipolytic isolates

\begin{tabular}{|c|c|c|c|c|c|}
\hline $\begin{array}{l}\text { Sl. } \\
\text { No }\end{array}$ & Isolate ID & Species identified & $\begin{array}{c}\text { GenBank } \\
\text { Accession } \\
\text { number }\end{array}$ & $\begin{array}{c}\text { Fish } \\
\text { proteolytic } \\
\text { activity }(\mathrm{U} / \mathrm{ml})\end{array}$ & $\begin{array}{c}\text { Fish lipolytic } \\
\text { activity (EI) }\end{array}$ \\
\hline 1 & CMFRI/BTr-01 & Bacillus tropicus & MT497555 & 0.586 & 0.36 \\
\hline 2 & CMFRI/StE-06 & Staphylococcus epidermidis & MK696596 & 0.448 & 0.5 \\
\hline 3 & CMFRI/StE-05 & S. epidermidis & MT491104 & 1.214 & 0.8 \\
\hline 4 & CMFRI/BS-25 & Bacillus subtilis & MT497470 & 1.59 & 0 \\
\hline 5 & CMFRI/SHo-02 & Staphylococcus hominis & MT491728 & 0.665 & 1.14 \\
\hline 6 & CMFRI/BA-17 & Bacillus amyloliquifaciens & MT498460 & 0.528 & 1 \\
\hline 7 & CMFRI/BS-29 & B. subtilis & MT501514 & 0.649 & 0 \\
\hline 8 & CMFRI/PaA-01 & Paenibacillus alvei & MT498618 & 1.893 & 0 \\
\hline 9 & CMFRI/BS-30 & B. subtilis & MT501517 & 1.921 & 0 \\
\hline 10 & CMFR1/BF-02 & Bacillus flexus & MT498618 & 0.757 & 0 \\
\hline 11 & CMFR1/BS-26 & B. subtilis & MT491143 & 0.632 & 0 \\
\hline 12 & CMFRI/BS-28 & B. subtilis & MT501515 & 1.091 & 0 \\
\hline 13 & CMFRI/BS-27 & B. subtilis & MT498779 & 1.458 & 0 \\
\hline 14 & CMFR1/Bva-01 & Bacillus vallismortis & MT498781 & 0.558 & 0 \\
\hline 15 & CMFRI/StCa-01 & Staphylococcus caprae & MK713757 & 0 & 0.78 \\
\hline 16 & CMFRI/BA-16 & B. amyloliquifaciens & MK713818 & 0 & 0.68 \\
\hline 17 & CMFR1/PaP-01 & Paenibacillus pinisoli & MT498847 & 0 & 0.3 \\
\hline 18 & CMFR1/PSt-01 & Pantoea stewartii & MT498672.1 & 0 & 0.2 \\
\hline 19 & CMFR1/Csa-01 & Cronobacter sakazakii & MT505511.1 & 0 & 0.9 \\
\hline
\end{tabular}




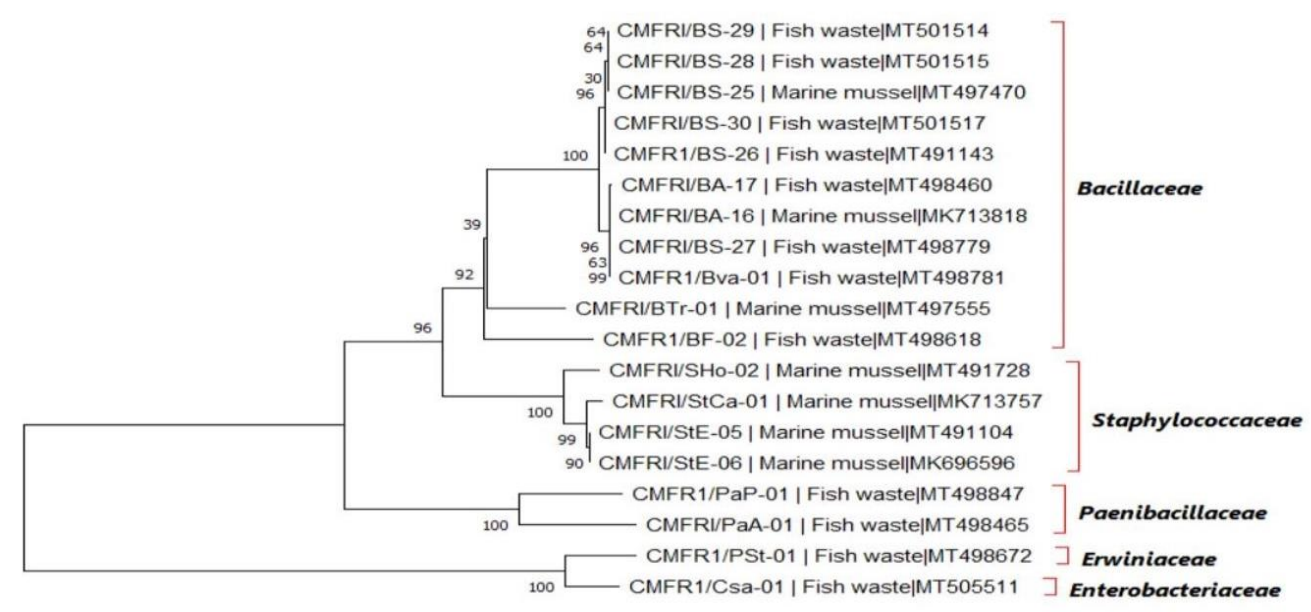

0.050

Figure 4. Neighbor-joining tree of fish proteolytic and fish lipolytic isolates based on 16SrRNA gene ID of each isolate was followed by the source of isolate and GenBank accession numbers

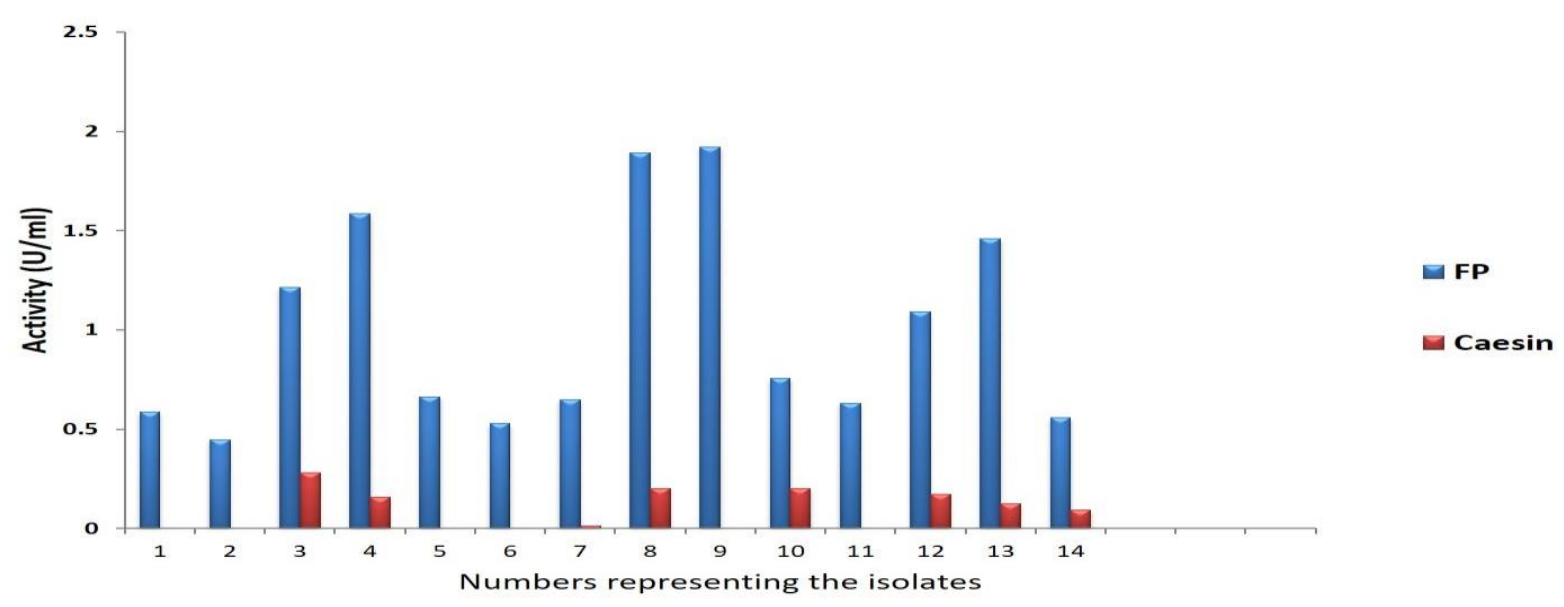

Figure 5. Validation results of fish protein hydrolysis

Abbreviations: FP: Fish protein; 1: CMFRI/BTr-01; 2: CMFRI/StE-06; 3: CMFRI/StE-05; 4: CMFRI/BS-25; 5: CMFRI/SHo-02; 6: CMFRI/BA-17; 7 : CMFRI/BS-29; 8: CMFRI/PaA-01; 9: CMFRI/BS-30; 10: CMFRI/BF-02; 11: CMFRI/BS-26; 12: CMFRI/BS-28; 13: CMFRI/BS-27; 14: CMFR1/Bva-01

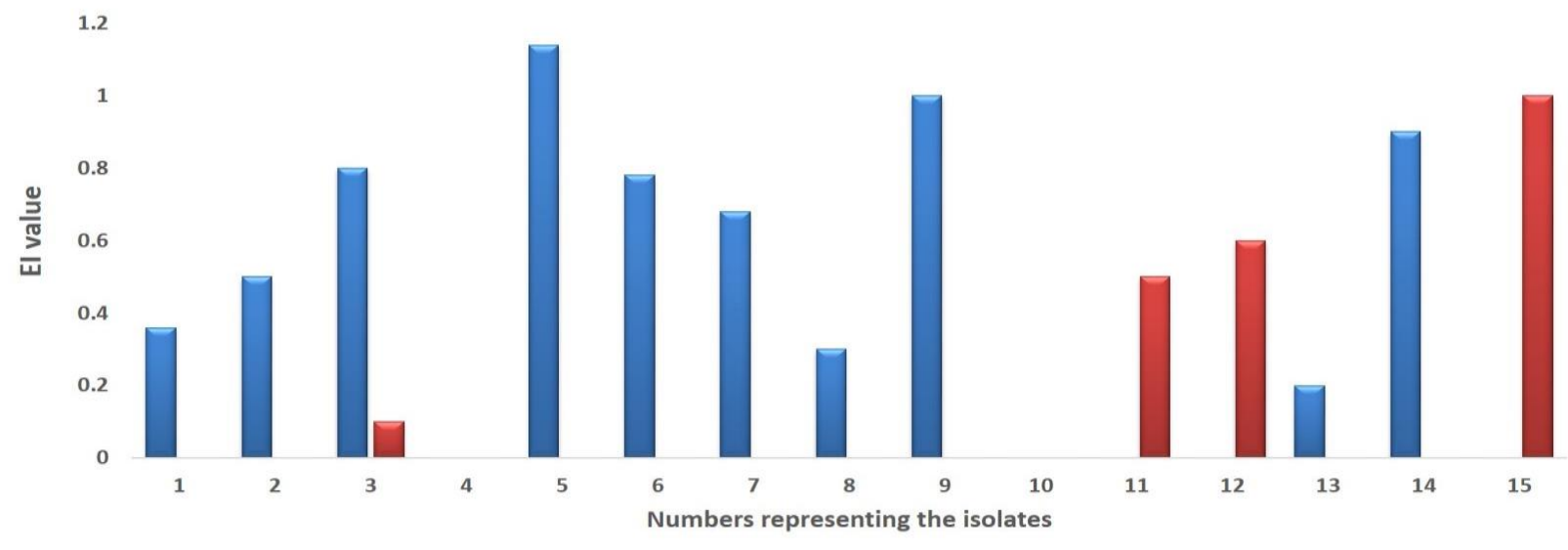

FO T80

Figure 6. Validation results of fish oil hydrolysis Abbreviations: T80: Tween 80; FO: Fish oil

1: CMFRI/BTr-01; 2: CMFRI/StE-06; 3: CMFRI/StE-05; 4: CMFRI/BS-25; 5: CMFRI/SHo-02; 6: CMFRI/StCa-01; 7: CMFRI/BA-16; 8: CMFR1/PaP-01; 9: CMFRI/BA-17; 10: CMFRI/BS-29; 11: CMFRI/PaA-01; 12: CMFRI/BF-02; 13: CMFR1/PSt-01; 14: CMFR1/Csa-01; 15: CMFRI/BS-27 
has not been reported. The isolates having the maximum fish proteolytic potential were identified as $B$. subtilis (CMFRI/BS-30) and P. alvei (CMFRI/PaA-01) (Fig. $5)$. In concordance to our results, $B$. subtilis was already identified as a potential candidate for fish protein digestion by different authors (Wang et al., 2019). Fish oil degrading microbes of the present study were belonging to 5 different genera namely, Bacillus spp., Cronobacter sp., Paenibacillus spp. and Pantoea sp., and Staphylococcus spp. Among different species, Bacillus amyloliquifaciens (CMFRI/BA-17) and $S$. hominis (CMFRI/SHo-02) were identified as the potential fish oil hydrolyzing microbes (Florencio et al., 2012) (Fig. 6). Lipolytic activity of B. amyloliquifaciens, Bacillus flexus, $B$. subtilis and $S$. epidermidis on fish oil has been explored earlier (Wang et al., 2019). The present study forms the first report on the fish oil hydrolyzing capacity of B. tropicus, Cronobacter sakazakii, P. alvei, Paenibacillus pinisoli, P. Pantoea stewartii, S. hominis and Staphylococcus caprae. Microbial lipases or microbes hydrolyzing fish oil are actively sought out for various industrial applications (Xiao et al., 2017). Very recently, Chandra et al. (2020) has highlighted the need for finding out novel microbial lipase/ microbes in fish waste management, warranting future research on the identified fish oil hydrolyzing microbes of the present study.

\section{Conclusions}

In short, the present paper provides the first evidence on the substrate specificity of fish proteolytic and fish lipolytic microbes, and proves that fish based substrates are the best and adequate candidates in primary screening as well as subsequent validation methodologies, during exploration of microbes/enzymes for fish waste management. The results further warn that using non-specific substrate in screening assays can lead to miss many positive hits. Further, the findings advocate that fish oil (FO) based phenol red plate assay and fish protein (FP) based plate assay can be good indicators of FO/FP degrading potential. The findings fetch applications in microbial functional screening for fish waste management, to have cost and time effective methodologies. Beyond methodological perspectives, the observed fish proteolytic/lipolytic potential isolates opens the possibility of utilizing them for the production of valuable byproducts from fish waste.

\section{Ethical Statement}

Ethical committee approval was not required for this study as the study did not involve any live animal experiments. Further, the authors affirm that all the experiments in the study and preparation of the manuscript were done in accordance with ethical responsibilities of authors' "Turkish Journal of Fisheries and Aquatic Science", guidance for authors.

\section{Funding Information}

This work was supported by ICAR-CMFRI funded project "Marine food fish, ornamental fish and lobster nutrition research for mariculture (MBT/NTM/24)". Further, APV acknowledges CSIR-UGC for her research fellowship.

\section{Author Contribution}

STG and RKJ conceived of the presented idea, supervised the findings and wrote the manuscript. APV executed the experimental design and combined the observations. AVN and SP provided technical support to carry out experiments. VP supervised the project and facilitated the experiments.

\section{Conflict of Interest}

There is no conflict of interest to report.

\section{Acknowledgements}

The authors are grateful to the Director, Indian Council of Agricultural Research (ICAR) - Central Marine Fisheries Research Institute (CMFRI), Kochi for providing necessary research facilities. APV acknowledges CUSAT (Cochin University of Science and Technology, Cochin) for her PhD registration.

\section{References}

Anson, M. L. (1938). The estimation of pepsin, trypsin, papain, and cathepsin with hemoglobin. Journal of General Physiology, 22(1), 79-89. https://doi.org/10.1085/jgp.22.1.79

AOAC (Association of Official Analytical Chemists). 2003. Official methods of analysis of the association of official's analytical chemists. Seventeenth ed. Arlington, Virginia.

Araujo, J., Sica, P., Costa, C., \& Márquez, M. C. (2020). Enzymatic hydrolysis of fish waste as an alternative to produce high value-added products. Waste and Biomass Valorization, 12(2), 847-855. https://doi.org/10.1007/s12649-020-01029-x

Bandarra, N. M., Batista, I., Nunes, M. L., \& Empis, J. M. (2001). Seasonal variation in the chemical composition of horsemackerel (Trachurus trachurus).

European Food Research Technology, 212, 535-539. https://doi.org/10.1007/s002170100299

Belchior, S.G., \& Vacca, G. (2006). Fish protein hydrolysis by a psychrotrophic marine bacterium isolated from the gut of hake (Merluccius hubbsi). Canadian Journal of Microbiology, 52, 1266-1271.

https://doi.org/10.1139/w06-083

Bergey, D., Whitman, W., Goodfellow, M., Kaampfer, P., \& Busse, H. (2012). Bergey's manual of Systematic Bacteriology. Springer, New York.

Bligh, E.G., \& Dyer, W.J. (1959). A rapid method of total lipid extraction and purification. Canadian Journal of Biochemistry and Physiology, 37, 911-917. https://doi.org/ 10.1139/059-099 
Chalamaiah, M., Kumar, D.B., Hemalatha, R., \& Jyothirmayi, T. (2012). Fish protein hydrolysates: proximate composition, amino acid composition, antioxidant activities and applications: a review. Food Chemistry, 135, 3020-3038.

https//doi.org/10.1016/j.foodchem.2012.06.100

Chandra, P., Singh, R., \& Arora, P. K. (2020). Microbial lipases and their industrial applications: a comprehensive review. Microbial Cell Factories, 19(1), 1-42.

Daroit, D. J., \& Brandelli, A. (2014). A current assessment on the production of bacterial keratinases. Critical reviews in biotechnology, 34(4), 372-384. https//doi:.org/10.3109/07388551.2013.794768.

Dauda, A.B., Ajadi, A., Tola-Fabunmi, A.S., \& Akinwole, A.O. (2019). Waste production in aquaculture: Sources, components and managements in different culture systems. Aquaculture and Fisheries, 4 (3), 81-88. https://doi.org/10.1016/j.aaf.2018.10.002.

De Lourdes Moreno., Pérez, D., García, M.T., \& Mellado, E. (2013). Halophilic bacteria as a source of novel hydrolytic enzymes. Life, 3(1), 38-51. https/doi.org/10.3390/life3010038.

De Oliveira C.T., Pellenz, L., Pereira, J.Q., Brandelli, A., \& Daroit, D.J. (2016). Screening of bacteria for protease production and feather degradation. Waste Biomass Valorization, 7(3), 447-453.

https://doi.org/10.1007/s12649-015-9464-2

Fernandes, P. (2016). Enzymes in fish and seafood processing. Frontiers in Bioengineering and Biotechnology, 4, 59.

https://doi.org/10.3389/fbioe.2016.00059

Fungaro, M.H.P., \& Maccheroni, Jr., W. (2002). Genetic improvement for enzyme production applied to the food industry. In I.S. Melo., M.C. Valadares-Inglis., L.L. Nass. \& Valois, A. C. C (Eds.). Genetic Resources and Improvement-Microorganism (pp. 426-453) EmbrapaMeioAmbiente. Jaguariúna.

George-Okafor, U.O., \& Mike-Anosike, E.E. (2012). Screening and optimal protease production by Bacillus sp. Sw-2 using low cost substrate medium. Research Journal of Microbiology, 7(7), 327-336.

https://doi.org/10.3923/jm.2012.327.336

Ghosh, A., Maity, B., Chakrabarti, K., \& Chattopadhyay, D. (2007). Bacterial diversity of east Calcutta wet land area: Possible identification of potential bacterial population for different biotechnological uses. Microbial Ecology, 54, 452-459. doi: 10.1007/s00248-007-9244-z. https://doi.org/10.1007/s00248-007-9244-z.

Gopinath, S.C., Anbu, P., \& Hilda, A. (2005). Extracellular enzymatic activity profiles in fungi isolated from oil-rich environments. Mycoscience, 46(2), 119-126. https://doi.org/10.1007/s10267-004-0221-9

Haki, G.D., \& Rakshit, S.K. (2003). Developments in industrially important thermostable enzymes: a review. Bioresource Technology, 89, 17-34. https://doi.org/ 10.1016/s09608524(03)00033-6.

Hammer, O., Harper, D.A., \& Ryan, P.D. (2001). PAST: Paleontological statistics software package for education and data analysis. Palaeontologia Electronica, 4(1), 9. http://palaeo-electronica.org

Ilko, D., Braun, A., Germershaus, O., Meinel, L., \& Holzgrabe, U. (2015). Fatty acid composition analysis in polysorbate 80 with high performance liquid chromatography coupled to charged aerosol detection. European Journal of Pharmacecutics and Biopharmacecutics, 94, 569574. https://doi.org/ 10.1016/j.ejpb.2014.11.018

Janda, J.M., \& Abbott, S.L. (2007). 16S rRNA gene sequencing for bacterial identification in the diagnostic laboratory: pluses, perils, and pitfalls. Journal of Clinical Microbiology, 45, 2761-2764.

https://doi.org/10.1128/JCM.01228-07

Kristinsson, H.G., \& Rasco, B.A. (2000). Biochemical and functional properties of Atlantic salmon (Salmosalar) muscle proteins hydrolyzed with various alkaline proteases. Journal of Agriculture and Food Chemistry, 48(3), 657-666. https://doi.org/ 10.1021/jf990447v

Kumar, S., Stecher, G., Li, M., Knyaz, C., \& Tamura, K. (2018). MEGA X: molecular evolutionary genetics analysis across computing platforms. Molecular Biology and Evolution, 35(6), 1547-1549.

https://doi.org/10.1093/molbev/msy096

Lanka, S., \& Latha, J.N.L. (2015). A short review on various screening methods to isolate potential lipase producers: Lipases-the present and future enzymes of biotech industry. International Journal of Biological Chemistry, 9(5): 207-19. https://doi.org/10.3923/ijbc.2015.207.219

Motyan, J.A., Toth, F., \& Tozser, J. (2013). Research applications of proteolytic enzymes in molecular biology. Biomolecules, 3(4), 923-942. https://doi.org/10.3390/biom3040923

Rai, A. K., Swapna, H. C., Bhaskar, N., Halami, P. M., \& Sachindra, N. M. (2010). Effect of fermentation ensilaging on recovery of oil from fresh water fish viscera. Enzyme and Microbial Technology, 46(1), 9-13.

Ramakrishnan, V. V. (2013). Extraction of proteins from mackerel fish processing waste using alcalase enzyme. Journal of Bioprocessing and Biotechniques, 3(2), 1-9. https://doi.org/10.4172/2155-9821.1000130

Ramnath, L., Sithole, B., \& Govinden, R. (2017). Identification of lipolytic enzymes isolated from bacteria indigenous to Eucalyptus wood species for application in the pulping industry. Biotechnology Reports, 15, 114-124. https://doi.org/10.1016/j.btre.2017.07.004

Rastall, R. ed. (2007). Novel enzyme technology for food applications. Elsevier.

Rebeca, B.D., Pena-Vera, M.T., \& Diaz-Castaneda, M. (1991). Production of fish protein hydrolysates with bacterial proteases; yield and nutritional value. Journal of Food Science, 56(2), 309-314. https://doi.org/10.1111/j.1365-2621.1991.tb05268.x

Rudolf, A.F., Skovgaard, T., Knapp, S., Jensen, L.J., \& Berthelsen, J. (2014). A comparison of protein kinases inhibitor screening methods using both enzymatic activity and binding affinity determination. PloS one, 9(6). https://doi.org/10.1371/journal.pone.00988 00

Ruginescu, R., Gomoiu, I., Popescu, O., Cojoc, R., Neagu, S., Lucaci, I., ... \& Enache, M. (2020). Bioprospecting for Novel Halophilic and Halotolerant Sources of Hydrolytic Enzymes in Brackish, Saline and Hypersaline Lakes of Romania. Microorganisms, 8(12), 1903. https://doi.org/10.1186/s12934-020-01428-8

Samad, N.S.A., Amid, A., Jimat, D.N. \& Shukor, N.A.A. (2017). Protease purification from Bacillus amyloliquefaciens B7 using aqueous two-phase system (ATPS). International Food Research Journal, 24(Suppl.)

Sharma, K. M., Kumar, R., Panwar, S., \& Kumar, A. (2017). Microbial alkaline proteases: Optimization of production 
parameters and their properties. Journal of Genetic Engineering and Biotechnology, 15(1), 115-126. https://doi.org/10.1016/j.jgeb.2017.02.001

Siddik, M.A.B., Howieson, J., Fotedar, R., \& Partridge, G.J. (2021). Enzymatic fish protein hydrolysates in finfish aquaculture: a review. Reviews in Aquaculture, 13, 406430. $10.1111 /$ raq. 12481

Singh, R., Gupta, N., Goswami, V.K., \& Gupta, R. (2006). A simple activity staining protocol for lipases and esterases. Applied Microbiology and Biotechnology, 70(6), 679-682. https://doi.org/10.1007/s00253-005-0138-z

Singh, R., Kumar, M., Mittal, A., \& Mehta, P.K. (2016). Microbial enzymes: Industrial progress in $21^{\text {st }}$ century. 3 Biotech, 6(2), 174. https://doi.org/10.1007/s13205016-0485-8

Soleymani, S., Alizadeh, H., Mohammadian, H., Rabbani, E., Moazen, F., Sadeghi, H.M., Shariat, Z.S., Etemadifar, Z. \& Rabbani, M. (2017). Efficient media for high lipase production: One variable at a time approach. Avicenna Journal of Medical Biotechnology, 9(2), 82.

Sumathi, C., Mohanapriya, D., Mandal, A. B., \& Sekaran, G. (2012). Production of different proteases from fish gut microflora utilizing tannery fleshing. Engineering in Life Sciences, 12(2), 223-237.

https://doi.org/10.1002/elsc.201100097
USDEC (U.S. Dairy Export Council). (2005). Reference manual for U.S. milk powders, Arlington, Virginia.

Villamil, O., Váquiro, H., \& Solanilla, J.F. (2017). Fish viscera protein hydrolysates: Production, potential applications and functional and bioactive properties. Food Chemistry, 224, 160-171. https://doi.org/ 10.1016/j.foodchem.2016.12.057

Wang, C.H., Doan, C.T., Nguyen, V.B., Nguyen, A.D., \& Wang, S.L. (2019). Reclamation of fishery processing waste: a mini-review. Molecules, 24, 2234. https://doi.org/10.3390/molecules24122234

Weisburg, W. G., Barns, S. D. M., Pelletier, D. A., \& Lane, D. J. (1991). 16S ribosomal DNA amplification for phylogenetic study. Journal Bacteriology, 173, 697703. https://doi.org/10.1128/jb.173.2.697-703.1991

Wisuthiphaet, N., Klinchan, S., \& Kongruang, S. (2016). Fish protein hydrolysate production by acid and enzymatic hydrolysis. KUMTNB International Journal of Applied Science Technology, 9(4), 261-270. https://doi.org/10.14416/j.ijast.2016.11.004

Xiao, W., Chen, X., Jing, X., \& Zhu, B. (2018). A meta-analysis of soil extracellular enzyme activities in response to global change. Soil Biology and Biochemistry, 123, 21-32. https://doi.org/10.1016/j.soilbio.2018.05.001 